\title{
Cross-Cultural Competence of Personality and Adaptation to Polycultural Environment: Approaches and Techniques
}

\author{
Kostenko Dmytro \\ Ph.D., Associate Professor, \\ Taras Shevchenko National University (Kyiv, Ukraine)
}

Karam Ahmed
Postgraduate student
Donbass State Pedagogical University (Slavyansk, Ukraine)

Honchar Liubov

Ph.D., Associate Professor

Donbass State Pedagogical University (Slavyansk, Ukraine)

\author{
Ternopilska Valentyna \\ Doctor of Pedagogical Sciences, Professor \\ Dragomanov National Pedagogical University (Kyiv, Ukraine)
}

\section{Chernukha Nadiia}

Doctor of Pedagogical Sciences, Professor

Taras Shevchenko National University (Kyiv, Ukraine)

\begin{abstract}
The article considers the cross-cultural competence of an individual as an important factor influencing the success of adaptation of various categories of people immigrants, refugees and internally displaced persons, returnees, representatives of ethnic and cultural minorities, as well as representatives of multicultural societies. Based on foreign studies, different approaches to the development of practical programs aimed at increasing intercultural competence and the effectiveness of socio-cultural adaptation are analyzed.

In many cases, the fate and career of a person depends on successful intercultural interaction. Cultural differences become a particularly important factor when a person is forced or voluntarily in another sociocultural environment, where he must deal with various life and business tasks. Ignorance of cultural values, roles, norms and rules of conduct can be a major obstacle in international political and business negotiations, on the way to survival in a new culture and achievement of goals and education. In addition to knowledge of another culture, the skills and abilities that will determine the realization of this knowledge, as well as the desire to overcome all obstacles and to succeed in activities in intercultural interaction are necessary.

The combination of knowledge, personality traits, motives and specific skills that contribute to the effective achievement of goals in intercultural interaction, was called intercultural competence. This complex theoretical construct, extremely needed in practice, has attracted the attention of a huge number of researchers and developers of practical programs.

Thus, the approaches discussed give a broad opportunity to choose methods and technologies for solving problems that arise in intercultural interaction. Despite the general tendency to develop complex methods, the specific approaches, as shown above, continue to exist and develop, taking into account the latest advances in this field. Traditional methods, such as lectures, case studies, role-playing games, game simulators, the method
\end{abstract}


of critical incidents are enriched with video materials, the use of computer self-diagnosis, interactive video and online learning.

Key words: cross-cultural competence, sociocultural adaptation, training programs, techniques, personality, ethnic minorities.

\section{1. ВСТУП}

Постановка проблеми. У сучасному світі знання іноземних мов та особливостей інших культур стають життєвою необхідністю для величезної кількості людей. Причини зрозумілі. За останні п’ятдесят років сталася низка подій, що прискорило спілкування між різними народами, культурами та країнами: це і розпад колоніальних систем, і розширення міжнародних контактів у виробничій сфері, торгівлі та науці, що сформувалися завдяки розвитку нових технологій загальному інформаційному простору, безперервному руху мігрантів з одних країн до інших.

У багатьох випадках від успішної міжкультурної взаємодії залежить доля і кар'єра людини. Культурні відмінності стають особливо важливим фактором, коли людина вимушено або добровільно опиняється в іншому соціокультурному середовищі, де їй необхідно вирішувати різні життєві і ділові завдання. Незнання культурних цінностей, ролей, норм і правил поведінки може виявитися значною перепоною у міжнародних політичних і ділових перемовинах, на шляху виживання в новій культурі та досягнення поставлених цілей й отримання освіти. Крім знань про іншу культуру необхідні вміння та навички, що визначатимуть реалізацію цих знань, а також бажання подолати всі перешкоди і досягти успіху у діяльності в міжкультурній взаємодії.

Сукупність знань, особистісних особливостей, мотивів і конкретних навичок, що сприяють ефективному досягненню цілей в міжкультурній взаємодії, отримала назву міжкультурної компетентності. Цей складний теоретичний конструкт, надзвичайно потрібний в практиці, привернув увагу величезної кількості дослідників і розробників практичних програм.

Мета статті. На основі аналізу зарубіжних досліджень щодо різних підходів до розробки практичних програм, які впливають на успішність адаптації особистості виявити можливі методи і технології спрямовані на підвищення міжкультурної компетентності та ефективності соціокультурної адаптації. 
Аналіз останніх досліджень і публікацій. Термін «компетентність» був введений в теорію і практику міжкультурної комунікації дослідниками, які почали вивчати діяльність іноземного технічного персоналу і добровольців Корпусу миру [31].Упродовж півстоліття дослідження проводилися в контексті теорій адаптації і акультурації різних категорій мігрантів в іншому культурному середовищі $[9 ; 13 ; 49]$, концепції культурного шоку [1; 6; 7; 18; 19; 45; 47], в практичних підходах до кроскультурного навчання [33], консультування та психотерапії іноземців в іншій культурі $[2 ; 29 ; 39 ; 40 ; 46]$, в дослідженнях міжнародних відносин і ділової взаємодії різних культур [4; 10; 14; 40].

\section{2. РЕЗУЛЬТАТИ ДОСЛІДЖЕННЯ}

Окремі риси сучасного світу призвели до усвідомлення педагогами, психологами, культурологами, лінгвістами, антропологами необхідності розробки спеціальних програм, спрямованих на оптимізацію міжкультурної взаємодії. Не тільки вузькі фахівці, а й представники найрізноманітніших сфер, почали усвідомлювати важливість розробки практичних програм 3 підвищення міжкультурної компетентності, зокрема педагоги, які навчають представників різних етнічних груп, керівники підприємств, де працюють фахівці з різних країн, фахівці і співробітники різних служб, які працюють з різними категоріями мігрантів.

За кілька десятиліть зарубіжними фахівцями були накопичені грунтовні дані, які свідчили про те, що більшість людей, залучених до кроскультурної взаємодії, отримують істотну користь від певного виду систематичної підготовки і тренінгів, які допомагають їм впоратися зі стресом і культурним шоком. Занурення людини в нову культуру без спеціальної підготовки може мати занадто високу ціну як з фінансової, так і з особистісної сторони.

Однією зі значних проблем для міжнародних компаній і організацій нерідко стає масове передчасне повернення працівників і членів їх родин. $Є$ дані, що від 20\% до 50\% людей, які виїжджають працювати за кордон, повертаються раніше терміну закінчення контракту $[16 ; 17 ; 20 ; 48]$. Це приносить великі збитки. Так, за даними американських дослідників, у фінансовому плані для всієї індустрії США загальна вартість робітника може досягати двох мільярдів доларів на рік [15; 24], що у 
3-5 разів може перевищувати його зарплату; ціна кожної невдачі може коливатися в межах від чверті до мільйона доларів США на одного працівника $[11 ; 27 ; 35]$.

Ця проблема не обмежується тільки експатріацією співробітників різних організацій. Наприклад, аналіз діяльності представників Корпусу миру, організації де працюють волонтери, які на старті проходять психологічне обстеження і консультування [34], показав, що показник відсіву за період з $1961-1971$ рр. склав 40-50\% [36; 37]. Також іноземні студенти 3 поганою успішністю $є$ сумнівним вкладенням коштів для своїх країн, сімей і університетів. Навіть у тих людей, які на постійній основі включаються в нову культуру - іммігрантів і біженців, можуть виникати додаткові труднощі, що перешкоджають успішній адаптації. У всіх випадках невдалої адаптації, крім соціальних втрат, є ще й особистісна ціна для кожної окремої людини у вигляді зниження самооцінки, уповільнення професійної кар'єри і відчуття себе невдахою. При цьому страждають не тільки конкретні індивідууми, але також і їх сім’ї $[12 ; 15 ; 26 ; 29]$. Є ще й прихована ціна, зокрема кумулятивний вплив таких подій на міжнаціональну і міжгрупову гармонію.

Відтак, наразі є досить багато емпіричних і юридичних підстав, що визначають надзвичайну важливість організації систематичних міжкультурних програм для людей, що включаються в незнайому культуру. Однак, більшість 3 них або взагалі не отримують ніякого формального навчання, або тільки отримують поверхневі знання, недостатні для інтелектуальних і особистісних ресурсів, необхідних для успішної адаптації. Існують вагомі причини, чому така підготовка відсутня. Для багатьох країн культурний тренінг виявляється дорогим заняттям. $€$ також причини, що перешкоджають проведенню таких тренінгів. Наприклад, у людей, що опиняються в іншій культурі, може бути відсутня мотивація до участі у тренінгу або можуть виникати серйозні організаційні труднощі. Прикладом можуть служити біженці. Прагнення змінити місце проживання, необхідність їх термінового переселення, небезпека для їхнього життя і здоров'я, звичайно, не залишає можливості для їх попередньої культурної орієнтації.

Студенти, які навчаються за кордоном за фінансової підтримки урядів своїх країн або університетів, іноді проходять попередню підготовку. Але у зв'язку із дефіцитом 
фахівців, що володіють необхідною теоретичною і емпіричною базою, таке навчання часто не приносить очікуваної користі.

Зараз найбільша увага приділяється підготовці до міжкультурної взаємодії, яка здійснюється в сфері бізнесу, так як все більше число керівників мультинаціональних компаній усвідомлюють, що це підвищує ефективність їх функціонування. У той же час інші категорії людей, які опиняються в іншому культурному середовищі, - біженці, співробітники благодійних організацій, технічний персонал - залишаються практично без уваги [27].

Коло людей, яким необхідні практичні міжкультурні програми, досить широке. Це - іммігранти, вимушені переселенці і біженці, репатріанти, представники етнічних і культурних меншин, а також представники мультикультурних суспільств з високим рівнем міжетнічної напруженості і ксенофобії. Наведемо ці категорії людей, які змінюють своє місце проживання вимушено або добровільно, на нетривалий час або на все життя, з точки зору можливостей їх спеціальної підготовки до життя в новому соціокультурному середовищі з метою більш успішної адаптації.

1. Іммігранти - категорія людей, яка в першу чергу, потребує серйозної підготовці до життя в новому соціокультурному середовищі. У такій ситуації ефективні культурно-специфічні програми, що дозволяють їм пристосуватися до нових соціокультурних умов. Іммігранти, як і люди, які приїжджають в іншу країну на певний термін, переживають особливий стан, що отримав назву «культурний шок». Згаданий феномен уперше описав Карл Оберг, який стверджував, що входження в нову культуру для кожної людини є заплутаним, турбуючим i дезорганізуючим переживанням. Таке сильне нервове збудження може статися під впливом нових умов, коли сенсорні, символічні, вербальні і невербальні системи, які безперебійно забезпечували б нормальне життя на батьківщині, відмовляються адекватно працювати.

Концепція культурного шоку в тому вигляді, в якому вона була сформульована Карлом Обергом, спиралася на так званий клінічний підхід до вивчення процесів адаптації в іншій культурі. Його прихильники вважали, що невдачі і проблеми іммігрантів - це симптоми прихованої патології, що потребує лікування. У вітчизняній психіатрії розлади адаптації також нерідко пов’язували з поняттям «Ситуаційного 
розладу» і розглядалися як «неправильні» реакції на події та обставини життя. Карл Оберг виділив шість основних психологічних ознак культурного шоку: напруга, яка супроводжує зусилля, необхідні для психологічної адаптації; відчуття втрати або позбавлення (статусу, друзів, батьківщини, професії, майна); відчуття знедоленої людини (неприйняття новою культурою) і відчуття відкидання (неприйняття нової культури); збій у рольовій структурі (ролях, очікуваннях); плутанина в самоідентифікації, цінностях, почуттях; відчуття тривоги, засноване на різних емоціях (здивування, відраза, обурення), що виникають в результаті усвідомлення культурних відмінностей; відчуття неповноцінності внаслідок нездатності впоратися 3 новою ситуацією [43].

Проте надалі культурний шок стали розглядати як нормальну реакцію, як частину звичайного процесу адаптації до нового культурного оточення. Багато дослідників намагалися уточнити розуміння культурного шоку, підкреслюючи різні сторони перебування в іншій культурі. Для цього використовувалися терміни «культурне стомлення» [34] «мовний шок» [45], «рольовий шок» [23] та ін. Зокрема, П. Бок описав культурний шок як емоційну реакцію, що виникає внаслідок нездатності зрозуміти, проконтролювати і передбачити поведінку інших [19]. До подібних переживань призводить недостатне знайомство як 3 новими фізичними умовами (наприклад, вид будинків, магазинів, установ), так і 3 соціальним оточенням (наприклад, звичаї, етикет, ритуали). Інші автори пов'язували культурний шок із невизначеністю норм та очікувань, отже, з труднощами контролю над ситуацією і їі прогнозуванням. У зв'язку з цим виникає тривожність, замішання і апатія, що тривають доки, поки не сформуються нові когнітивні конструкти для розуміння іншої культури і вироблення відповідних моделей поведінки.

Пом'якшення i подолання культурного шоку, допомога в соціальній i психологічній адаптації - основні завдання практичних міжкультурних програм для імігрантів, біженців та вимушених переселенців.

2. Біженці і вимушені переселенці. Будь-яка людина, що опинилася в іншокультурному середовищі, може переживати стрес акультурації, культурний шок, проте стан біженців і вимушених переселенців погіршується через травми, отримані до переїзду і невизначеністю їх стану в сьогоденні. Тому при розробці міжкультурних 
програм для цієї категорії осіб необхідно враховувати специфіку їх психологічного стану і паралельно з програмами міжкультурної взаємодії здійснювати програми реабілітаціі і психологічної допомоги в груповій або індивідуальній формі. Специфіка даної категорії людей у порівнянні з іммігрантами полягає також в тому, що невідомо, на який термін вони залишаться в країні, чи будуть вони репатрійовані або переселені до іншої країни, тому в програмах міжкультурної взаємодії для біженців акцент повинен бути зміщений в бік меншої культурної специфічності, і більш важливим виявляється розвиток загальної культурної сенситивності.

3. Особи, які перебувають тимчасово. Так називають зазвичай людей, що приїжджають в іншу країну на певний термін - від декількох місяців до декількох років. До цієї категорії осіб в першу чергу відносяться студенти, які навчаються за кордоном, співробітники міжнародних організацій, іноземних фахівці та члени їх родин. До цієї категорії входять і представники бізнесу. В умовах все більшої глобалізації економіки від рівня міжкультурної компетентності сучасного бізнесмена залежить не тільки його суб’єктивне відчуття комфорту міжкультурної комунікації, - на карту поставлена успішність міжнародної угоди, благополуччя організації, а часом - й економіка регіону.

Завдання, які стоять перед особами, які тимчасово перебувають, полягають в тому, щоб впоратися 3 вимогами нових культур i розвинути певний рівень соціокультурної компетентності, необхідний для успішної адаптації. У практичних програмах, розрахованих на дану категорію людей, необхідно враховувати різні аспекти, пов'язані зі специфікою когнітивних, афективних і поведінкових процесів. У когнітивному плані новоприбулі потребують інформування про політичні, соціальні та адміністративні приписи країни перебування, особливо про ті, які безпосередньо впливають і регулюють їх життя. Вони повинні усвідомити, що ці правила можуть мати як формальні, так і неформальні прояви. Емоційно вони повинні навчитися долати відсутність звичних місць, соціальних зв’язків і практик, 3 тривогою, яка визначається цими втратами, і намагатися знаходити приємне, що задовольняє їх в нових обставинах. У поведінковому аспекті вони повинні засвоїти новий репертуар міжособистісних і соціальних навичок, щоб ефективно взаємодіяти 3 партнерами 3 приймаючої культури [18; 30; 50]. 
4. Репатріанти. До цієї категорії осіб відносяться люди, що повертаються додому після тривалого перебування в іншій країні. Повернувшись в свою рідну культуру, до колишніх зв'язків, колишньої роботи, вони нерідко потребують спеціальних програм репатріації [38]. Ці програми необхідні, щоб сприяти так званому «зворотньому переходу» - поверненню до своєї культури, і особливо важливі для тих осіб, які тимчасово перебувають в іншій країні та довго були за кордоном i, що парадоксально, були успішні в соціокультурній адаптації. Окрема і важлива тема в контексті реадаптації репатріантів - професійна інтеграція. Адже після кількох років, проведених за кордоном, умови на роботі на батьківщині можуть після повернення здатися більш незвичними, ніж ті, що були в іншій країні.

5. Представники етнічних і культурних меншин. У літературі описані тренінги для членів груп меншин в мультикультурних суспільствах, включаючи аборигенів в країнах, які були масово заселені представниками колонізаторів. Міжкультурні програми для корінних мешканців і меншин спрямовані на розвиток мультикультурної компетентності, тобто на сприяння ефективному функціонуванню як у власній культурі, так і в домінуючій культурі, яка їх поглинула. Основна мета таких програм полягає в тому, щоб їх учасники не втратили вихідної культурної ідентичності, і щоб вони не прагнули до заміни однієї культури на іншу [42].

6. Представники мультикультурних суспільств. Як правило, представники приймаючої культури або етнічної більшості не отримують будь-якої освіти щодо інших культур. У даний час в більшості мультикультурних країн, в тому числі, і в Україні, поки не є можливим і фінансово доцільним повсюдно проводити таке навчання. Однак там, де є для цього ресурси, має сенс впровадження програми для зацікавлених учасників. Обов'язковою ж представляється підготовка до міжкультурного взаємодії тих представників приймаючого суспільства, які за родом своєї діяльності працюють в тісному контакті з представниками інших культур. До них відносяться співробітники служб і організацій для мігрантів і біженців, медичні працівники та психологи, що працюють з відповідними клієнтами, представники туристичного бізнесу, співробітники мультинаціональних організацій.

Особливу групу в цій категорії складають педагоги, які працюють в багатонаціональних освітніх установах. Педагог грає провідну роль в процесі 
соціалізації студента, виступаючи в якості посередника між суспільством і тим, хто навчається в процесі засвоєння культурно-історичного досвіду. Від викладача залежить створення сприятливої соціальної ситуації розвитку, необхідної для успішної життєдіяльності, індивідуального самовираження кожного студента i всебічного розвитку кожної особистості, збереження неповторності та розкриття іï потенційних здібностей, формування моральних цінностей і духовних орієнтирів. Педагог здатний чинити серйозний вплив на формування толерантної, полікультурної особистості студентів, ефективно функціонуючої в системі міжетнічних і міжконфесійних відносин.

Варто взяти до уваги, що педагогічний колектив несе в собі величезний потенціал підвищення міжкультурної компетентності та сприяння адаптації студентів з сімей мігрантів і етнічних меншин до освітнього середовища. Від професійності викладачів, їх світоглядних позицій і особистісних рис часто залежить те, наскільки комфортно в закладі освіти будуть відчувати себе студенти з різних соціокультурних груп. Готовність викладача прийняти інших такими, якими вони $є$ i взаємодіяти з ними на основі згоди, його стійкість до різноманіття світу, до етнічних, культурних, соціальних і світоглядних відмінностей створює передумови для підвищення міжкультурної компетентності студентів.

Відтак, стає очевидною необхідність спеціальної роботи 3 педагогами, психологами та адміністрацією освітніх закладів, спрямованої на забезпечення працівників освіти знаннями і навичками, що сприяють зростанню їх міжкультурної компетентності [5;8].

Досвід, накопичений в різні періоди розвитку практичних програм 3 підвищення міжкультурної компетентності та сприяння соціокультурній адаптації, ставить перед дослідниками завдання їх систематизації. Спираючись на закордонні і вітчизняні спроби аналізу даної проблеми (Солдатова, Шайгерова, Каліненко, Кравцова; Стефаненко; Brislin, Landis, Brandt; Gudykunst, Hammer; Ward, Bochner, Furnham), виділимо п'ять підходів до розробки міжкультурних програм, спрямованих на підвищення міжкультурної компетентності та ефективності соціокультурної адаптації: університетський, порівняльно-культурний, емпіричний, атрибутивний і комплексний. 
Університетський nidxid. Головне завдання даного підходу - надання учасникам різної інформації про ту чи іншу культуру. Знайомство з особливостями приймаючої культури може здійснюватися за допомогою методичної літератури, лекцій, групових дискусій, відеофільмів, за допомогою використання комп'ютерних засобів. Надана інформація може включати дані про економіку приймаючої країни, клімат, умови життя, повсякденну поведінку, стилі прийняття рішень, а також про типовий досвід і проблеми людей, які опинилися в іншій культурі.

Головна перевага даного підходу полягає в тому, що всі технології, на які він спирається, досить добре розроблені. Однак, його ефективність обмежена наступними моментами: інформація про культуру часто носить загальний характер і важка для застосування в конкретних умовах; пред'явлена інформація, як правило, екзотична, при цьому ігноруються звичайні, повсякденні ситуації; нерідко створюється помилкове враження, що культура може бути засвоєна за декілька занять; навіть якщо отримані факти зберігаються в пам'яті, вони зовсім не обов'язково забезпечують адекватну поведінку. Однак, незважаючи на всю критику, університетський підхід в силу багатьох причин досі залишається популярним. Означене одночасно охоплює багато людей, він простий, гнучкий і відносно недорогий.

Порівняльно-культурний пiдxiд. Головне завдання даного підходу -досягання культурної обізнаності через порівняння з цінностями і нормами інших культур. Формування та підвищення міжкультурної компетентності особистості в рамках цього підходу відбувається шляхом ознайомлення 3 відмінностями між власними культурними цінностями і нормами і цінностями іншої культури. Програми, засновані на ідеї культурної сенситивності, покликаної не тільки забезпечити учасників інформацією про іншу культуру, а й посилити у них усвідомлення власної культури. Метою програм такого роду є порівняння і протиставлення двох культур, розгляд відмінностей в поведінці з огляду кожної з двох культур і розвитку на цій основі усвідомлення культурної відносності. Програми культурної сенсибілізації i самоусвідомлення мають такі ж обмеження, як і побудовані тільки на інформуванні, зокрема, щодо перенесення отриманих в аудиторії знань на «польові умови» [18; 30; $50]$.

Атрибутивний niдxid. У цьому підході основна увага спрямована на 
пояснення поведінки з точки зору представника іншої культури. Його мета - навчити учасників тренінгу тим атрибуціям, які використовуються в досліджуваній культурі, i пояснити їх причини. Найбільш поширеним методом у рамках даного підходу $є$ культурний асимілятор. Культурний асимілятор включає описи епізодів зустрічей двох індивідів з різних культур, які заздалегідь оцінюються експертами (мандрівниками, знавцями даних культур) як проблемні ситуації. Кожна 3 описаних интеракцій завершується непорозумінням, нерозумінням або міжособистісною ворожістю. Учаснику пропонується потім чотири або п'ять альтернативних обгрунтувань невдалої взаємодії, відповідних типів атрибуції спостережуваної поведінки. Тільки одна з цих атрибуцій $\epsilon$ адекватною i коректною 3 погляду культурного навчання. Учасники вибирають відповіді, які вони вважають вірними [21; 22]. Недолік цього методу у тому, що він пов'язаний із когнітивним навчанням і страждає від уже згаданих обмежень, властивих інформаційному підходу.

Емпіричний підхід. Емпіричні методи стали відповіддю на обмеження всіх попередніх підходів, що носять інформаційно-орієнтований характер. Незадоволеність практиків використанням методів тільки такого роду привела до різних спроб розробити психотехнології, спрямовані на усвідомлення і спостереження реальних або штучно створених переживань, пов'язаних із засвоєнням іншої культури. Ключова відмінність навчання, заснованого на досвіді, полягає в тому, що його учасники максимально залучені в процес. Мета емпіричного навчання - ознайомити учасників 3 життям в іншій країні шляхом активного отримання досвіду всередині чужої культури або в ситуації іï імітації. Перевага такого підходу полягає в тому, що він дозволяє учасникам на власному досвіді засвоювати навички, необхідні для життя в приймаючій культурі.

Комплексний підхід. 3 огляду на недоліки всіх перерахованих підходів, фахівці в даній практичній галузі все більше віддають перевагу розробці комплексних інтегративних програм, в яких поєднуються різні технології, запозичені 3 вищевказаних підходів. Однією з перших була комплексна модель формування та підвищення міжкультурної компетентності особистості, запропонована Гудіканстом і Хаммером [32], яка заснована на двох вимірах: з одного боку, це вибір дидактичного (університетського) або емпіричного (досвідченого) методу розробки групових 
психотехнологій. 3 іншого - вибір культурно-спільних або культурно-загальних технологій.

У контексті розробки спеціальних тренінгових програм співвідношення цих вимірів утворює чотири варіанта тренінгів [32]:

1. Емпіричний тренінг, що не орієнтований на конкретну культуру. До цього типу відносяться тренінги відносин. Згідно розробок Фостер і Данієлян, в результаті такого тренінгу здобуваються навички, які не можуть бути отримані в умовах навчальної аудиторії. Ще один варіант програм цього типу -міжкультурні семінари. Вони навчають міжкультурній взаємодії через дискусії в малих групах, що складаються з людей різних культур. У методах загальнокультурного моделювання, які також відносяться до цього типу, загальною характеристикою є активне залучення учасників тренінгу в моделювання культурних відмінностей [22; 51].

2. Емпіричний культурно-специфічний тренінг. Програми, що входять в цю категорію, включають модифікації традиційного тренінгу відносин і біхевіоральнокогнітивного тренінгу в контексті певної культури, а також семінари на тему міжкультурних комунікацій, організовані в контексті двох культур [25].

3. Дидактичний загальнокультурний тренінг. Такі тренінги фокусуються на дидактичних або оглядових методах навчання, щоб навчити загальнокультурним принципам. 3 зазначених вище, два основні підходи відповідають цьому типу технологій: традиційний інформаційний підхід - лекції з міжкультурної комунікації, культурної антропології та кроскультурної психології [3; 44] і метод культурного самоусвідомлення [41].

4. Дидактичний культурно-специфічний тренінг. $\mathrm{У}$ цю категорію можна включити традиційне навчання іноземної мови, інструктаж з огляду місцевості (орієнтування), культурні асимілятори та ін.

\section{3. ВИСНОВКИ}

Таким чином, розглянуті підходи дають широку можливість вибору методів і технологій для вирішення проблем, що виникають в міжкультурній взаємодії. Незважаючи на загальну тенденцію до розробки комплексних методів, специфічні підходи, як було показано вище, продовжують існувати і розвиватися, враховуючи новітні досягнення в цій сфері і традиційні методи, такі як лекції, case-study, рольові 
ігри, ігри-симулятори, метод критичних інцидентів збагачуються відеоматеріалами, застосуванням комп'ютерної самодіагностики, інтерактивним відео та інтернетнавчанням.

\section{References}

1. Lyuis R.D. Delovyie kulturyi v mezhdunarodnom biznese: ot stolknoveniya $k$ vzaimoponimaniyu [Business cultures in international business: from collision to mutual understanding]. Moscow: Delo, 1999.

2. Pezeshkian N. Psihosomatika i pozitivnaya psihoterapiya [Psychosomatics and positive psychotherapy]. Moscow: Meditsina, 1996.

3. Petko L.V. Vykhovnyi potentsial metodu sytuatsiinoho analizu ("Case study» method) u formuvanni profesiino oriientovanoho inshomovnoho navchalnoho seredovyshcha $v$ umovakh universytetu [Educational potential of the «Case study» method for the forming of the professionally oriented foreign language teaching environment in the conditions of university]. Naukovyi chasopys NPU imeni M.D.Drahomanova. Seriia 17. Teoriia i praktyka navchannia ta vykhovannia : zb. nauk. pr.; za red. akademika V.I.Bondaria. - Kyiv: Vyd-vo NPU imeni M.P.Drahomanova, 2015. Issue 27. P. 133-140.

4. Pet'ko L.V. Philosophical and linguistic ideas of interpersonality communication in professional sphere. Naukovi zapysky NaUOA. Ostrog : Vyd-vo «Ostroz'ka akademija», 2015. Serija «Filologichna». Issue 53. Pp. 353-356.

5. Soldatova G.U., Shaygerova L.A., Makarchuk A.V., Huhlaev O.E., Schepina A.I. Pozvol drugim byit drugimi [Allow to other to be other]. Moscow: Tsentr SMI MGU im. M.V Lomonosova, 2002.

6. Soldatova G.U., Lyutaya T.A., Makarchuk A.V., Shaygerova L.A., Schepina A.I. Raznyie, no ravnyie: bolshie psihologicheskie igryi [Different, but equal: large psychological games]. Moscow: Tsentr SMI MGU im. MV Lomonosova, 2004.

7. Soldatova G.U., Makarchuk A.V. Mozhet li drugoy stat drugom: trening po profilaktike ksenofobii [Whether other can to become a friend: training on the prophylaxis of ксенофобии]. Moscow: Genezis, 2006.

8. Soldatova G.U., Panteleev A.B. Osnovnyie aspektyi psihologo-pedagogicheskoy rabotyi po socio-kulturnoy adaptatsii $v$ obrazovatelnoy srede [Basic aspects of phychopedagogical work on social-cultural adaptation in an educational environment]: mat. nauchno-prakt. konf. ASOU. Moscow, 2006.

9. Soldatova G. U., Shaygerova L. A., Makarchuk A. V. Treningi povyisheniya mezhkulturnoy kompetentnosti [Training of increase of cross-cultural competence]. Moscow: MGU im. M.V. Lomonosova, 2005.

10. Soldatova G. U., Shaygerova L. A., Sharova O. D. Zhit v mire s soboy i drugimi: Trenning tolerantnosti dlya podrostkov [To live in the world with itself et al: Training tolerance for teenagers]. Moscow, Genezis, 2000.

11. Stefanenko T.G. Etnopsihologiya [psychology]. Moscow, 2001. 
12. Arvey R., Bhagat R., Salas E. Cross-cultural andcross-national issues in personnel and human resources management: Where do we go from here? In GR. Ferrris, K.M. Rowland (Eds.), Research in personnel and human resource managementю 1991. Vol. 9. Pp. 367-407). Greenwich, CT: JAI Press.

13. Berry J.W. Psychology of acculturation: Understanding individuals moving between cultures // R.W. Brislin (Ed.) Applied cross-cultural psychology. L., 1990, Pp. 232-253.

14. Berry J.W., Annis RC. Acculturative stress: The role of ecology, culture and differentiation. Journal of Cross-Cultural Psychology, 1974. Vol. 5. Pp. 382-406.

15. Bhagat R.S., Prien O.K. "Cross-cultural training in organizational contexts", Landis, D. and Brislin, R. (Eds), Handbook of Intercultural Training, 2nd ed., Sage, Thousand Oaks, CA, 1996. Pp. 216-230.

16. Black, J. S. Workrole transitions: a study of American expatriate managers in Japan, in Black, J.S. and Gregersen, H.B. (1991), Antecedents to Cross-cultural Adjustment for Expatriates in Pacific Rim Assignments. Human Relations, 1988. Vol. 44. No. 5. Pp. 497-515.

17. Black J. S., Gregersen H. B. 1990. Expectations, satisfaction, and intention to leave of American expatriate managers in Japan. International Journal of Intercultural Relations. 1990. Vol. 14: 485-506.

18. Bochner S. The social psychology of cross-cultural relations // S.Bochner (Ed.) Cultures in Contact: Studies in Cross-Cultural Interaction. Oxford: Pergamon, 1982.

19. Bock P. K. Culture shock. N.Y.: Alfred A. Knopf, 1970.

20. Brislin R. W., Landis D., Brandt M. E. Conzeptualisations of Intercultural Behavior and Training // Brislin R.W. (Ed.) Handbook of Intercultural Training.V.1, Elmsford, N.Y.: Pergamon Press, 1983 Pp. 1-35.

21. Brislin R. W. Understanding culture's influence on behavior. Fort Worth, TX: Harcourt Brace. 1993.

22. Brislin R. W., Pedersen P. Cross-Cultural Orientation Programs. New York: Gardner Press. 1976.

23. Byrnes F. C. Role shock: An occupational hazard of American technical assistants abroad. Annals of the American Academy of Political and Social Science, 1966. Vol. 368. Pp. 95-108.

24. Cascio W.F. Managing human resources: Productivity, quality of work life, profits. New York: McGraw-Hill, Inc. 1992.

25. David K. Intercultural adjustment and applications of reinforcement theory to problems of culture shock. Trends, 1972. Vol. 4. Pp. 1-64.

26. De Verthelyi Renata Frank. International student's spouses: invisible sojourners in the culture shock literature. International Journal of Intercultural Relations. 1995. Vol 19, $387-411$. 
27. Dinges N., Baldwin K. Intercultural competence: A research perspective. In D. Landis and R.S.Bhagat, (Eds.), Handbook of intercultural training, Thousand Oaks: Sage Publications. 1996. Pp. 106-123.

28. Draguns J. G. Ethnocultural considerations in the treatment of PTSD: Therapy and service delivery // Marsella A.J., Friedman M.J., Gerrity E.T., Scurfield R.M. (Eds.) Ethnocultural aspects of posttraumatic stress disorder: Issues, research, and clinical applications. Washington, American Psychological Association, 1996. Pp. 459-482.

29. Fontaine G. The experience of experiential training exercises: The Role of a sense of presence and other states. Communication Research Reports. 1996. 13(1).

30. Furnham A., Bochner S. Culture Shock: Psychological reactions to unfamiliar environments. London and New York, 1986.

31. Gardner, G. H. Cross-cultural communication. Journal of Social Psychology. 1962. 58, 241-256.2.

32. Gudykunst W. B. Intercultural communication theories. In W. Gudykunst, B. Mody (Eds.), Handbook of international and intercultural communication (2nd ed.). Thousand Oaks, CA: Sage, 2002.

33. Gudykunst W. B., Hammer M. R. Basic training design: Approaches to intercultural training. In D. Landis, R. Brislin (Eds.), Handbook of intercultural training. Elmsford, NY: Pergamon Press. 1983. Vol. 1.

34. Guthrie G. M. A behavioral analysis of culture learning // R. Brislin, S. Bochner, W. Lonner (Eds.) Cross-cultural perspectives on learning. N.Y.: Wiley, 1975.

35. Guzzo R., Noonan K., Elron E. (1994). «Expatriate Managers and the Psychological Contract.» Journal of Applied Psychology. 1994. Vol. 79(4): 617-626.

36. Harris J. G. Identification of cross-cultural talent: The empirical approach of the Peace Corps. Topics in Culture Learning. 1975. Vol. 3. Pp.66-78

37. Harris P. R., Moran R. T. Managing Cultural Differences: High Performance Strategies for a New World of Business. Houston: Gulf Publishing Company. 1991.

38. Harvey M. G. «Inpatriation» training: The next challenge fore international human resource management. International Journal of Intercultural Relations. 1997. Vol. 21(3). Pp. $393-428$.

39. Ivey A. E., Bradford-Ivey M., Simek-Morgan L., Cheatham H. E., Pedersen P. B., Rigazio-DiGilio S. A., Sue D. W. Counseling and psychotherapy: A multicultural perspective. Needham Heights, Mass., Allyn \& Bacon, 1997.

40. Koss-Chioino J. D., Vargas L. A. Through the looking glass: a model for understanding culturally responsive psychotherapies // Working with culture: Psychotherapeutic interventions with ethnic minority children and adolescents. San Francisco: Jossey-Bass Publ., 1992. Pp. 1-22.

41. Kraemer A. J. The intercultural experience as a planned learning experience. Alexandria, VA: Human Resources Research Organization.1981. Pp. 4-81. 
42. LaFromboise T., Coleman H., Gerton J. Psychological impact of biculturalism: Evidence and theory. Psychological Bulletin, 1993. November. Vol. 114(3). Pp. 395-412.

43. Oberg K. Culture shock: Adjustment to new cultural environments. Practical Anthropology. 1960. Vol. 7. Pp. 177-182.

44. Pet'ko Lyudmila. The "Case Study" Method as Means of Formation of a Professionally Oriented Foreign Language Teaching Environment in University Conditions. Intellectual Archive. 2015. Volume 4. No. 4 (July). Series "Education \& Pedagogy". Toronto : ShinyWordCorp. PP. 48-65.

45. Smalley W. Culture shock, language shock, and the shock of self-discovery. Practical Anthropology, 1963. Vol. 10. Pp. 49-56.

46. Sue D.W., Sue D. Counseling the culturally different: Theory and practice. N.Y.: John Wiley \& Sons, 1999. Pp. 208-232.

47. Triandis H. C., Triandis L. M. Race, social class, religion and nationality as determinants of social distance. Soc. Psychol. 1960. Vol. 61. Pp. 110-118.

48. Tung R. L. "Expatriate assignments: enhancing success and minimizing failure". Academy of Management Executive. 1987. Vol. 1 No. 2, Pp. 117-26.

49. Vega W. A., Rumbant R. G. Ethnic minorities and mental health. Ann. Rev. Sociol. Palo Alto, CA, 1991. Pp. 351-384.

50. Ward C., Furnham, A., Bochner S. The Psychology of Culture Shock. 2nd ed. East Sussex: Routledge. 2001.

51. Weeks W. H., Pedersen P. B., Brislin, R. W. (Eds.). A manual of structured experiences for cross-cultural learning. Washington, DC: Society for Intercultural Education, Training and Research. 1986.

Translation of the Title, Abstract and References to the Author's Language УДК (316.613/.614+316.723):177+303.446.2(051)

Костенко Д., Карам А., Гончар Л., Тернопільська В., Чернуха Н. Міжкультурна компетентність особистості та адаптація до полікультурного середовища: підходи та технології.

У статті розглядається міжкультурна компетентність особистості як важливий фактор, що впливає на успішність адаптації різних категорій людей, зокрема, іммігрантів, біженців та вимушених переселенців, репатріантів, представників етнічних і культурних меншин, а також представників мультикультурних суспільств. На основі зарубіжних досліджень аналізуються різні підходи до розробки практичних програм, спрямованих на формування міжкультурної компетентності та ефективності соціокультурної адаптації. Описано п’ять підходів до розробки міжкультурних програм, спрямованих на підвищення міжкультурної компетентності та ефективності соціокультурної адаптації: університетський, порівняльно-культурний, емпіричний, атрибутивний і комплексний.

Ключові слова: міжкультурна компетентність, соціокультурна адаптація, тренінгові програми, технології, особистість, етнічні меншини. 


\section{Література}

1. Льюис Р. Д. Деловые культуры в международном бизнесе: от столкновения к взаимопониманию. Москва: Дело, 1999.

2. Пезешкиан Н. Психосоматика и позитивная психотерапия. Москва: Медицина, 1996.

3. Петько Л. В. Виховний потенціал методу ситуаційного аналізу («Сase study» method) у формуванні професійно орієнтованого іншомовного навчального середовища в умовах університету. Науковий часопис НПУ імені М.Д.Драгоманова. Серія 17. Теорія і практика навчання та виховання : зб. наук. пр. ; за ред. академіка В.І.Бондаря. Київ: Вид-во НПУ імені М.П.Драгоманова, 2015. Вип. 27. С. 133-140.

4. Петько Л. В. Філософсько-лінгвістичні ідеї розуміння міжлюдської комунікації у соціальному середовищі. Наукові записки Наџіонального університету «Острозька академія». Серія «Філологічна» : зб. наук. праць / укл. І.В.Ковальчук, Л.М.Коцюк, С.М.Новоселецька. - Острог: Вид-во Національного ун-ту «Острозька академія», 2015. Вип. 53. С. 309-312.

5. Солдатова Г. У., Шайгерова Л. А., Макарчук А. В., Хухлаев О. Е., Щепина А. И. Позволь другим быть другими. Москва: Центр СМИ МГУ им. М. В. Ломоносова, 2002.

6. Солдатова Г. У., Лютая Т. А., Макарчук А. В., Шайгерова Л. А., Щепина А. И. Разные, но равные: большие психологические игры. Москва: Центр СМИ МГУ им. М.В. Ломоносова, 2004.

7. Солдатова Г. У., Макарчук А. В. Может ли другой стать другом: тренинг по профилактике ксенофобии. Москва: Генезис, 2006.

8. Солдатова Г. У., Пантелеев А. Б. Основные аспекты психолого-педагогической работы по социо-культурной адаптации в образовательной среде: матер. научно-практ. конф. АСОУ. Москва, 2006.

9. Солдатова Г. У., Шайгерова Л. А., Макарчук А. В. Тренинги повышения межкультурной компетентности. Москва: МГУ им. М. В. Ломоносова, 2005.

10. Солдатова Г. У., Шайгерова Л. А., Шарова О. Д. Жить в мире с собой и другими: Тренинг толерантности для подростков. Москва, Генезис, 2000.

11. Стефаненко Т.Г. Этнопсихология. Москва, 2001.

12. Arvey R. D., Bhagat R. S. \& Salas E. Cross-cultural andcross-national issues in personnel and hu- man resources management: Where do we go from here? In G.R. Ferrris, K.M. Rowland (Eds.). Research in personnel and human resource management. Greenwich, CT: JAI Press. 1991. Vol. 9. Pp. 367-407.

13. Berry J. W. Psychology of acculturation: Understanding individuals moving between cultures // R. W. Brislin (Ed.) Applied cross-cultural psychology. L., 1990. Pp. 232-253. 
14. Berry J. W., Annis R. C. Acculturative stress: The role of ecology, culture and differentiation. Journal of Cross-Cultural Psychology, 1974. Vol. 5. Pp. 382-406.

15. Bhagat R. S., Prien O. K. "Cross-cultural training in organizational contexts", Landis, D. and Brislin, R. (Eds). Handbook of Intercultural Training, 2nd ed., Sage, Thousand Oaks, CA, 1996. Pp. 216-230.

16. Black, J. S. Workrole transitions: a study of American expatriate managers in Japan, in Black, J.S. and Gregersen, H.B. Antecedents to Cross-cultural Adjustment for Expatriates in Pacific Rim Assignments. Human Relations. 1991. Vol. 44. No. 5. Pp. 497-515.

17. Black J. S., Gregersen H. B. 1990. Expectations, satisfaction, and intention to leave of American expatriate managers in Japan. International Journal of Intercultural Relations. 1990. Vol. 14: 485-506.

18. Bochner S. The social psychology of cross-cultural relations // S.Bochner (Ed.) Cultures in Contact: Studies in Cross-Cultural Interaction. Oxford: Pergamon, 1982.

19. Bock P. K. Culture shock. N.Y.: Alfred A. Knopf, 1970.

20. Brislin R. W., Landis D., Brandt M. E. Conzeptualisations of Intercultural Behavior and Training // Brislin R.W. (Ed.) Handbook of Intercultural Training.V.1, Elmsford, N.Y.: Pergamon Press, 1983 Pp. 1-35.

21. Brislin R. W. Understanding culture's influence on behavior. Fort Worth, TX: Harcourt Brace. 1993.

22. Brislin R. W., Pedersen P. Cross-Cultural Orientation Programs. New York: Gardner Press. 1976.

23. Byrnes F. C. Role shock: An occupational hazard of American technical assistants abroad. Annals of the American Academy of Political and Social Science, 1966. Vol. 368. Pp. 95-108.

24. Cascio W.F. Managing human resources: Productivity,. quality of work life, profits. New York: McGraw-Hill, Inc. 1992.

25. David K. Intercultural adjustment and applications of reinforcement theory to problems of culture shock. Trends, 1972. Vol. 4. Pp. 1-64.

26. De Verthelyi Renata Frank. International student's spouses: invisible sojourners in the culture shock literature. International Journal of Intercultural Relations, 1995. Vol 19, 387-411.

27. Dinges N., Baldwin K. Intercultural competence: A research perspective. In D. Landis and R.S.Bhagat, (Eds.), Handbook of intercultural training, Thousand Oaks: Sage Publications. 1996. Pp. 106-123.

28. Draguns J. G. Ethnocultural considerations in the treatment of PTSD: Therapy and service delivery // Marsella A.J., Friedman M.J., Gerrity E.T., Scurfield R.M. (Eds.) Ethnocultural aspects of posttraumatic stress disorder: Issues, research, andclinicalapplications. Washington, American Psychological Association, 1996. Pp. 459-482. 
29. Fontaine G. The experience of experiential training exercises: The Role of a sense of

presence and other states. Communication Research Reports. 1996. 13(1).

30. Furnham A., Bochner S. Culture Shock: Psychological reactions to unfamiliar environments. London and New York, 1986.

31. Gardner G.H. Cross-cultural communication. Journal of Social Psychology. 1962. Vol. 58, 241-256.2

32. Gudykunst W. B. Intercultural communication theories. In W.Gudykunst, B. Mody (Eds.), Handbook of international and intercultural communication (2nd ed.). Thousand Oaks, CA: Sage, 2002.

33. Gudykunst W. B., Hammer M. R. Basic training design: Approaches to intercultural training. In D. Landis, R. Brislin (Eds.), Handbook of intercultural training. Elmsford, NY: Pergamon Press. 1983. Vol. 1.

34. Guthrie G. M. A behavioral analysis of culture learning // R. Brislin, S. Bochner, W. Lonner (Eds.) Cross-cultural perspectives on learning. N.Y.: Wiley, 1975.

35. Guzzo R., Noonan K., Elron E. «Expatriate Managers and the Psychological Contract.» Journal of Applied Psychology, 1994. Vol. 79(4): 617-626.

36. Harris J. G. Identification of cross-cultural talent: The empirical approach of the Peace Corps. Topics in Culture Learning. 1975. Vol. 3. Pp.66-78

37. Harris P. R., Moran R. T. Managing Cultural Differences: High Performance Strategies for a New World of Business. Houston: Gulf Publishing Company. 1991.

38. Harvey M. G. «Inpatriation» training: The next challenge fore international human resource management. International Journal of Intercultural Relations. 1997. Vol. 21(3). Pp. $393-428$.

39. Ivey A. E., Bradford-Ivey M., Simek-Morgan L., Cheatham H. E., Pedersen P. B., Rigazio-DiGilio S. A., Sue D. W. Counseling and psychotherapy: A multicultural perspective. Needham Heights, Mass., Allyn \& Bacon. 1997.

40. Koss-Chioino J. D., Vargas L. A. Through the looking glass: a model for understanding culturally responsive psychotherapies // Working with culture: Psychotherapeutic interventions with ethnic minority children and adolescents. San Francisco: Jossey-Bass Publ., 1992. Pp. 1-22.

41. Kraemer A. J. The intercultural experience as a planned learning experience. Alexandria, VA: Human Resources Research Organization.1981. Pp. 4-81.

42. LaFromboise T., Coleman H., Gerton J. Psychological impact of biculturalism: Evidence and theory. Psychological Bulletin, 1993. November. Vol. 114(3). Pp. 395-412.

43. Oberg K. Culture shock: Adjustment to new cultural environments. Practical Anthropology. 1960. Vol. 7. Pp. 177-182.

44. Pet'ko Lyudmila. The "Case Study" Method as Means of Formation of a Professionally Oriented Foreign Language Teaching Environment in University Conditions. 
Intellectual Archive. 2015. Volume 4. No. 4 (July). Series "Education \& Pedagogy". Toronto : ShinyWordCorp. PP. 48-65.

45. Smalley W. Culture shock, language shock, and the shock of self-discovery. Practical Anthropology. 1963. Vol. 10. Pp. 49-56.

46. Sue D.W., Sue D. Counseling the culturally different: Theory and practice/ N.Y.: John Wiley \& Sons, 1999. Pp. 208-232.

47. Triandis H. C., Triandis L. M. Race, social class, religion and nationality as determinants of social distance. Soc. Psychol. 1960. Vol. 61. Pp. 110-118.

48. Tung R. L. "Expatriate assignments: enhancing success and minimizing failure". Academy of Management Executive. 1987. Vol. 1 No. 2, pp. 117-26.

49. Vega W. A., Rumbant R. G. Ethnic minorities and mental health. Ann. Rev. Sociol. Palo Alto, CA, 1991. Pp. 351-384.

50. Ward C., Furnham, A., Bochner S. The Psychology of Culture Shock. 2nd ed. East Sussex: Routledge. 2001.

51. Weeks W. H., Pedersen P. B., Brislin, R. W. (Eds.). A manual of structured experiences for cross-cultural learning. Washington, DC: Society for Intercultural Education, Training and Research. 1986. 